\title{
Implementation of vancomycin dosing nomogram in an electronic prescribing system: an innovative tool in antibiotic stewardship
}

\author{
Tácio de Mendonça Lima ${ }^{1,2, *}$, Sabrina Calil Elias ${ }^{1}$, Rita de Cássia Elias Estrela², \\ Fernando Luiz Lopes Cardoso ${ }^{3}$
}

\author{
${ }^{1}$ Department of Pharmacy, Fluminense Federal University, Rio de Janeiro, RJ, Brazil, ${ }^{2}$ Faculty of Pharmacy, Federal \\ University of Rio de Janeiro, Rio de Janeiro, RJ, Brazil, ${ }^{3}$ Hospital Infection Control Team, University Hospital Clementino \\ Fraga Filho, Rio de Janeiro, RJ, Brazil
}

\begin{abstract}
Vancomycin (VAN) is the gold standard therapy for Methicillin-resistant Staphylococcus aureus (MRSA) infections such as bacteremia and endocarditis. However, VAN suboptimal dosing for serious infections caused by $S$. aureus isolates that have elevated minimum inhibitory concentration (MIC), could be associated with poor outcome. Better understanding of VAN pharmacokinetics and pharmacodynamics (PK/PD) has led to the creation of new recommendations with optimized dosing regimens for the treatment of MRSA infections. For severe infectious, such as pneumonia and endocarditis, a VAN serum trough concentration of $15-20 \mathrm{mg} / \mathrm{L}$ at the steady state should be targeted. The aim of this study was to show how a nomogram with updated VAN dosing was devised and how it was implemented in the electronic prescribing (e-prescribing) system of a teaching hospital. VAN loading dose and maintenance doses were calculated from a pharmacokinetic equation using basic parameters: weight, estimated creatinine clearance, as well as peak and trough serum concentrations. The implementation of the VAN dosing nomogram in the hospital e-prescribing system definitively changed the long-standing medical prescription fallacy of "same dose fits all". Finally, this computer-based electronic program has allowed a wide-ranging intervention and should be recognized as a powerful tool for implementation in antimicrobial stewardship programs.
\end{abstract}

Uniterms: Vancomycin/prescribing. Methicillin/use. Staphylococcus aureus/methicillin-resistant. Electronic prescribing system/application in hospital. Antibiotics/rational use. Antimicrobials/rational use.

Vancomicina (VAN) é utilizada como primeira escolha na terapia de infecções causadas por Staphylococcus aureus resistentes à meticilina (MRSA), como bacteremia e endocardite. Entretanto, o aumento na concentração inibitória mínima (CIM) de isolados de S. aureus e doses subterapêuticas de VAN podem estar associados à falha terapêutica. Para o melhor entendimento sobre o perfil farmacocinético e farmacodinâmico (PK/PD) da VAN foram elaboradas novas recomendações para terapia de infecções causadas por MRSA. Para terapia de infecções graves, como pneumonia e endocardite, a concentração sérica do vale de VAN de 15-20 mg/L no estado de equilíbrio dinâmico deve ser o alvo. O objetivo do estudo foi desenvolver um nomograma com doses atualizadas de VAN e demonstrar como ele foi implementado no sistema de prescrição eletrônica em um Hospital Universitário. As doses de ataque e manutenção foram calculadas a partir de equações farmacocinéticas, utilizando parâmetros fundamentais: peso, depuração de creatinina, concentrações séricas do pico e do vale. A implementação de um nomograma de doses de VAN em um sistema de prescrição eletrônica modificou definitivamente o inadequado hábito de que "a mesma dose cabe em todos". Finalmente, esta abrangente ferramenta tecnológica deve ser considerada como uma robusta estratégia num programa de uso racional de antibióticos.

Unitermos: Vancomicina/prescrição. Meticilina/uso. Staphylococcus aureus/resistência à meticilina. Sistema de prescrição eletrônica/aplicação em hospitais. Antibióticos/uso racional. Antibacterianos/ uso racional.

\footnotetext{
*Correspondence: T. M. Lima.Rua Rodolpho Paulo Rocco, s/n, Bloco A,

$2^{\circ}$ andar, sala 52 - Ilha do Fundão, 21941-617 - Rio de Janeiro - RJ, Brasil.

E-mail: taciolima@superig.com.br
} 


\section{INTRODUCTION}

Methicillin-resistant Staphylococcus aureus (MRSA) is a major pathogen in hospital-acquired infections worldwide and, in some countries, has also become an emergent pathogen in community-acquired infections (David, Daum, 2010).

Alternative antimicrobial agents with proven efficacy against MRSA infections, such as linezolid, daptomycin and tigecycline, are available. However, except for daptomycin, these drugs are not FDA approved for the treatment of bacteremia and endocarditis. Vancomycin (VAN) remains the most widely used drug in clinical practice for MRSA infections and is comparatively less costly (Liu et al., 2011).

Better knowledge about VAN pharmacokinetics/ pharmacodynamics (PK/PD) has allowed proposals to optimize VAN dosing. $\mathrm{AUC}_{24 \mathrm{~h}} / \mathrm{MIC}$ (area under the plasma-concentration curve in 24 hours divided by the minimal inhibitory concentration) has been considered in animal models, and in a study involving humans with pneumonia caused by $S$. aureus, as the most representative PK/PD index for VAN. The study in humans showed that clinical outcome and bacteriological eradication were superior in patients who attained the VAN PK/PD index of $\geq 400 \mathrm{AUC}_{24 \mathrm{~h}} / \mathrm{MIC}$ (MoiseBroder et al., 2004). In addition, for $S$. aureus with VAN MIC of $1 \mathrm{mg} / \mathrm{L}$, the $\mathrm{AUC}_{24 \mathrm{~h}}$ of 400 would be necessary to reach the recommended PK/PD index of 400. It is noteworthy that for $S$. aureus with MIC $>1 \mathrm{mg} / \mathrm{L} \mathrm{VAN,}$ a higher dosing regimen would be necessary to achieve the recommended PK/PD target and the benefits of this are uncertain. Therefore, in this scenario, alternative drugs should be considered because of increased risk of VAN toxicity and clinical failure. The VAN serum trough concentration of $15 \mathrm{mg} / \mathrm{L}$ or greater is correlated to an $\mathrm{AUC}_{24 \mathrm{~h}}$ of around 400 , and higher doses are usually necessary to attain this target (Rybak et al., 2009). Based on these data, the Infectious Diseases Society of America (IDSA) and American Society of Health-System Pharmacists guidelines have updated VAN dosing to $15-20 \mathrm{mg} / \mathrm{kg}$ every $8-12$ hours targeting a trough serum concentration of 15 to $20 \mathrm{mg} / \mathrm{L}$ for the treatment of severe infections such as pneumonia, endocarditis, osteomyelitis and meningitis in adult patients (Rybak et al., 2009; Liu et al., 2011).

An electronic prescribing (e-prescribing) system is a technology that improves the quality of patient care and the safety of medication management by decreasing medical errors through the feature of electronically sending an accurate and understandable prescription directly to a pharmacy from the point-of-care. Utilization of electronic systems and e-prescribing in antibiotic stewardship programs are an encouraging innovative field but with limited reports to date (Tamma, Cosgrove, 2011).

The aim of this study was to show how a nomogram with an updated VAN dosing regimen for adults was devised using a linear PK model and how it was implemented in an e-prescribing system.

\section{MATERIAL AND METHODS}

This study is a report of the VAN nomogram calculation with individualized PK parameters, and how it was subsequently implemented. The study was conducted in a public teaching hospital with 300 beds for adult patients located in Rio de Janeiro city. The hospital utilizes the MedTrak systems, an integrated Electronic Medical Record and Medical Practice Management Software Service that allow electronic prescribing and many electronic surveillance tools including microbiological culture results, MRSA chart flagging, notification of new orders for VAN prescriptions and, since 2010, the provision of antibiotic dosing regimen orientation through e-prescribing. For the development of the VAN dosing nomogram, a one-compartment model (the Bauer model) was used. Individualized parameters were applied in the equations to calculate the VAN maintenance dose regimens with the following PK parameters: VAN clearance $\left(\mathrm{Cl}_{\text {vanco }}\right)$, volume of distribution $\left(\mathrm{V}_{\mathrm{d}}\right), \mathrm{K}$ elimination $(\mathrm{K})$, half-life $\left(\mathrm{t}_{1 / 2}\right)$ and dosing interval (DI). Total body weight in $\mathrm{kg}$ (TBW) and estimated creatinine clearance in $\mathrm{mL} / \mathrm{min}(\mathrm{ClCr})$ were stratified into ranges. For the dose calculations, the midpoint of each range was used to estimate the most adequate dose regimen for each patient category. For example, in patients in the TBW range of $71-80 \mathrm{~kg}$ and renal function with $\mathrm{ClCr}$ in the $50-59 \mathrm{~mL} / \mathrm{min}$ range, the values used in the equation were $75 \mathrm{~kg}$ and $55 \mathrm{~mL} / \mathrm{min}$, respectively. For patients with $\mathrm{ClCr} \geq 120 \mathrm{~mL} / \mathrm{min}$, the value used was $130 \mathrm{~mL} / \mathrm{min}$. The ClCr was calculated using the Cockcroft and Gault (1976) formula. VAN loading dose was calculated independently of renal function by multiplying TBW by $25 \mathrm{mg}$. The $\mathrm{ClCr}$ calculation and pharmacokinetic equations along with the variables employed are shown below:

\section{Estimated creatinine clearance}

$\mathrm{ClCr}_{(\mathrm{mL} / \mathrm{min})}=(140-\mathrm{A}) \times \mathrm{W} / \mathrm{SCr} \times 72$. For females, the final product is multiplied by 0.85 .

\section{VAN clearance \\ $\mathrm{Cl}_{\text {vanco }(\mathrm{mL} / \mathrm{min} / \mathrm{kg})}=0.695 \times(\mathrm{ClCr} / \mathrm{TBW})+0.05$}


Volume of distribution

$\mathrm{V}_{\mathrm{d}(\mathrm{L})}=0.7 \times \mathrm{TBW}$

Elimination rate constant

$\mathrm{K}_{\left(\mathrm{h}^{-1}\right)}=\mathrm{Cl}_{\text {vanco }} / \mathrm{V}_{\mathrm{d}}$

Half-life

$\mathrm{t}_{1 / 2(\mathrm{~h})}=0.693 / \mathrm{K}$

Dosing interval

DI $\left(\right.$ h) $=\ln$ Peak $_{\mathrm{d}}-\ln \operatorname{Trough}_{\mathrm{d}} / \mathrm{K}$

\section{Maintenance dose}

$\mathrm{MD}_{(\mathrm{mg})}=\operatorname{Peak}_{\mathrm{d}} \mathrm{x} \mathrm{V}_{\mathrm{d}} \mathrm{x}\left[1-\mathrm{e}^{-(\mathrm{K} \times \mathrm{DI})}\right]$

Symbol key: A represents age in years, W represents weight in $\mathrm{kg}$, $\mathrm{SCr}$ represents serum creatinine in $\mathrm{mg} /$ $\mathrm{dL}$, TBW represents total body weight, while Peak $\mathrm{d}_{\mathrm{d}}$ and Trough $_{\mathrm{d}}$ represent desired VAN serum peak and trough concentrations both in $\mathrm{mg} / \mathrm{L}$.

Peak and trough concentrations of VAN were selected as $50 \mathrm{mg} / \mathrm{L}$ and $17.5 \mathrm{mg} / \mathrm{L}$, respectively. This trough serum level is to achieve empirical optimal exposure to $S$. aureus with VAN MIC $\leq 1 \mathrm{mg} / \mathrm{L}$ according to MRSA VAN MIC distribution $\left(\mathrm{MIC}_{90}\right.$ ) from clinical samples obtained at our hospital. VAN infusion rate was applied according to doses: 60 minutes of infusion for doses $\leq 1.0 \mathrm{~g}, 90$ minutes for 1.1 to $1.5 \mathrm{~g}, 120$ minutes for 1.6 to $2.0 \mathrm{~g}$, and for doses $>2.0 \mathrm{~g}$ the infusion rate was around $1.0 \mathrm{~g} / \mathrm{h}$.

The dosing intervals were planned to reduce the unnecessary risk of developing toxicity by exposure to high doses (for instance $1.0 \mathrm{~g}$ q6h as opposed to $2.0 \mathrm{~g}$ $\mathrm{q} 12 \mathrm{~h}$ ) and to guarantee obtention of the desired trough level. Dosage regimens were rounded according to VAN dose vial $(500 \mathrm{mg})$ and to facilitate drug scheduling for nursing $(6,8,12,24$, and $96 \mathrm{~h})$. For patients on hemodialysis (i.e. $\mathrm{ClCr}<10 \mathrm{~mL} / \mathrm{min}$ ) the recommend drug interval was 4 days. It is important to consider that in this hospital, patients are submitted to hemodialysis using the low-flux dialyzer and that VAN removal by this type of dialyzer is negligible regardless of blood or dialysate flow. For patients whose weight was under $50 \mathrm{~kg}$ or over $100 \mathrm{~kg}$, it is recommended that assistance be sought to calculate VAN dosing individually.

\section{RESULTS AND DISCUSSION}

The VAN dosing nomogram for adults according to TBW and $\mathrm{ClCr}$ is shown in Table I. The nomogram includes six weight ranges from $\geq 50$ to $\leq 100 \mathrm{~kg}$ and 11 renal function ranges from patients on dialysis with $\mathrm{ClCr}<10 \mathrm{~mL} / \mathrm{min}$ to patients with $\mathrm{ClCr}>120 \mathrm{~mL} / \mathrm{min}$.

The computer based program with the nomogram is accessed when VAN is typed into the e-prescribing sheet by the physician. The nomogram dosing adjustment window with the requested parameters is then automatically triggered (Figure 1). The prescriber must input values for the variables TBW and $\mathrm{ClCr}$ into the window for automatic display of the VAN dosage regimen and rate of infusion. For the beginning of therapy, the system automatically marks the option of loading dose, whereas for subsequent days the option of loading dose is left unmarked by default.

TABLE I - Vancomycin dosing nomogram for adults according to total body weight and renal function

\begin{tabular}{|c|c|c|c|c|c|c|c|c|c|c|c|c|}
\hline $\begin{array}{l}\text { Weight } \\
(\mathrm{kg})\end{array}$ & $\begin{array}{c}\text { Loading } \\
\text { Dose }\end{array}$ & \multicolumn{11}{|c|}{ Maintenance Dose } \\
\hline $50-60$ & $1500 \mathrm{mg}$ & $\begin{array}{c}1000 \mathrm{mg} \\
\mathrm{q} 96 \mathrm{~h}\end{array}$ & $\begin{array}{c}500 \mathrm{mg} \\
\mathrm{q} 24 \mathrm{~h}\end{array}$ & $\begin{array}{c}750 \mathrm{mg} \\
\mathrm{q} 24 \mathrm{~h}\end{array}$ & $\begin{array}{c}500 \mathrm{mg} \\
\mathrm{q} 12 \mathrm{~h}\end{array}$ & $\begin{array}{c}500 \mathrm{mg} \\
\mathrm{q} 12 \mathrm{~h}\end{array}$ & $\begin{array}{c}750 \mathrm{mg} \\
\mathrm{q} 12 \mathrm{~h}\end{array}$ & $\begin{array}{c}750 \mathrm{mg} \\
\mathrm{q} 12 \mathrm{~h}\end{array}$ & $\begin{array}{c}1000 \mathrm{mg} \\
\mathrm{q} 12 \mathrm{~h}\end{array}$ & $\begin{array}{c}1250 \mathrm{mg} \\
\mathrm{q} 12 \mathrm{~h}\end{array}$ & $\begin{array}{c}1750 \mathrm{mg} \\
\mathrm{q} 12 \mathrm{~h}\end{array}$ & $\begin{array}{c}1750 \mathrm{mg} \\
\mathrm{q} 12 \mathrm{~h}\end{array}$ \\
\hline $71-80$ & $2000 \mathrm{mg}$ & $\begin{array}{c}1250 \mathrm{mg} \\
\mathrm{q} 96 \mathrm{~h}\end{array}$ & $\begin{array}{c}500 \mathrm{mg} \\
\mathrm{q} 24 \mathrm{~h}\end{array}$ & $\begin{array}{c}1000 \mathrm{mg} \\
\mathrm{q} 24 \mathrm{~h}\end{array}$ & $\begin{array}{c}750 \mathrm{mg} \\
\mathrm{q} 12 \mathrm{~h}\end{array}$ & $\begin{array}{c}750 \mathrm{mg} \\
\mathrm{q} 12 \mathrm{~h}\end{array}$ & $\begin{array}{c}1000 \mathrm{mg} \\
\mathrm{q} 12 \mathrm{~h}\end{array}$ & $\begin{array}{c}1000 \mathrm{mg} \\
\mathrm{q} 12 \mathrm{~h}\end{array}$ & $\begin{array}{c}1500 \mathrm{mg} \\
\mathrm{q} 12 \mathrm{~h}\end{array}$ & $\begin{array}{c}1000 \mathrm{mg} \\
\mathrm{q} 8 \mathrm{~h}\end{array}$ & $\begin{array}{c}1250 \mathrm{mg} \\
\mathrm{q} 8 \mathrm{~h}\end{array}$ & $\begin{array}{c}1000 \mathrm{mg} \\
\mathrm{q} 6 \mathrm{~h}\end{array}$ \\
\hline $81-90$ & $2000 \mathrm{mg}$ & $\begin{array}{c}1500 \mathrm{mg} \\
\mathrm{q} 96 \mathrm{~h}\end{array}$ & $\begin{array}{c}750 \mathrm{mg} \\
\mathrm{q} 24 \mathrm{~h}\end{array}$ & $\begin{array}{c}1250 \mathrm{mg} \\
\mathrm{q} 24 \mathrm{~h}\end{array}$ & $\begin{array}{c}750 \mathrm{mg} \\
\mathrm{q} 12 \mathrm{~h}\end{array}$ & $\begin{array}{c}1000 \mathrm{mg} \\
\mathrm{q} 12 \mathrm{~h}\end{array}$ & $\begin{array}{c}1000 \mathrm{mg} \\
\mathrm{q} 12 \mathrm{~h}\end{array}$ & $\begin{array}{c}1250 \mathrm{mg} \\
\mathrm{q} 12 \mathrm{~h}\end{array}$ & $\begin{array}{c}1500 \mathrm{mg} \\
\mathrm{q} 12 \mathrm{~h}\end{array}$ & $\begin{array}{c}1750 \mathrm{mg} \\
\mathrm{q} 12 \mathrm{~h}\end{array}$ & $\begin{array}{c}1000 \mathrm{mg} \\
\mathrm{q} 6 \mathrm{~h}\end{array}$ & $\begin{array}{c}1000 \mathrm{mg} \\
\mathrm{q} 6 \mathrm{~h}\end{array}$ \\
\hline
\end{tabular}


Updated renal function is notified by the electronic system for daily e-prescribing. For patients on hemodialysis, the prescriber must check the first box at the top (Patients on hemodialysis) then the $\mathrm{ClCr}$ of $9.0 \mathrm{~mL} / \mathrm{min}$ is selected automatically. For better control of the VAN prescription, a tool in the electronic chart that includes patient weight and height has been created. These patient parameters are displayed at the top right of the prescription sheet (Figure 1) allowing easy visual checking and when necessary, dose revision.

Severe infections caused by MRSA have to be promptly treated with the right choice of antimicrobial and dosing to achieve optimal drug exposure. Owing to increased MICs for VAN, more-intensive VAN dosing schedules have to be administered. VAN $1.0 \mathrm{~g} \mathrm{q} 12 \mathrm{~h}$ has been the standard dose regimen prescribed in our institution. There was a pressing need to definitively change this old practice of "same dose fits all", and therefore we decided to devise an updated VAN nomogram and implement this in the e-prescribing system. To our knowledge, this is the first report of a VAN dosing regimen nomogram implemented in an e-prescribing system at a Brazilian hospital.

Several VAN PK models, such as Matze, Birt, Ambrose, Burton and Bauer methods based on linear regression, and Bayesian estimations based on nonlinear regression, have been created to estimate the PK parameters of VAN to facilitate the initial drug dosing calculations. Although Bayesian PK models offer the advantage of calculating VAN dosing for a population database through the use of two or three compartment equations, these models are not widely used in the clinical field. They are also complex models that demand specialized PK knowledge and costly computer programs (Bauer, 2008).

We chose the Bauer method, a linear regression model that applies individualized PK equations and allows simplified and accurate VAN dosage calculations. In this method, the utilization of intravenous bolus constitutes a limitation. However, VAN elimination during intravenous infusion is poor and PK equations that consider the loss of drug during the infusion time are not obligatory, as intravenous bolus equations can predict VAN peak concentration (Bauer, 2008).

According to recent guidelines and other experts, the desirable VAN serum trough concentration should be in the 15 to $20 \mathrm{mg} / \mathrm{L}$ range (Rybak et al., 2009; Liu et al., 2011). Considering the recommendation of a loading dose, a study showed that patients with a $\mathrm{ClCr} 80 \mathrm{~mL} / \mathrm{min}$ who have received a VAN dose of $15 \mathrm{mg} / \mathrm{kg}$ q12h without a loading dose, only $23 \%$ achieved the desired serum target at $36 \mathrm{~h}$ (Drusano et al., 2007). In 2011, IDSA guidelines for MRSA therapy included the recommendation to administer a VAN loading dose of $25-30 \mathrm{mg} / \mathrm{kg}$ (TBW) in seriously ill patients with a limit of 2 -g per dose (Liu et al., 2011). In the present nomogram, a loading dose of

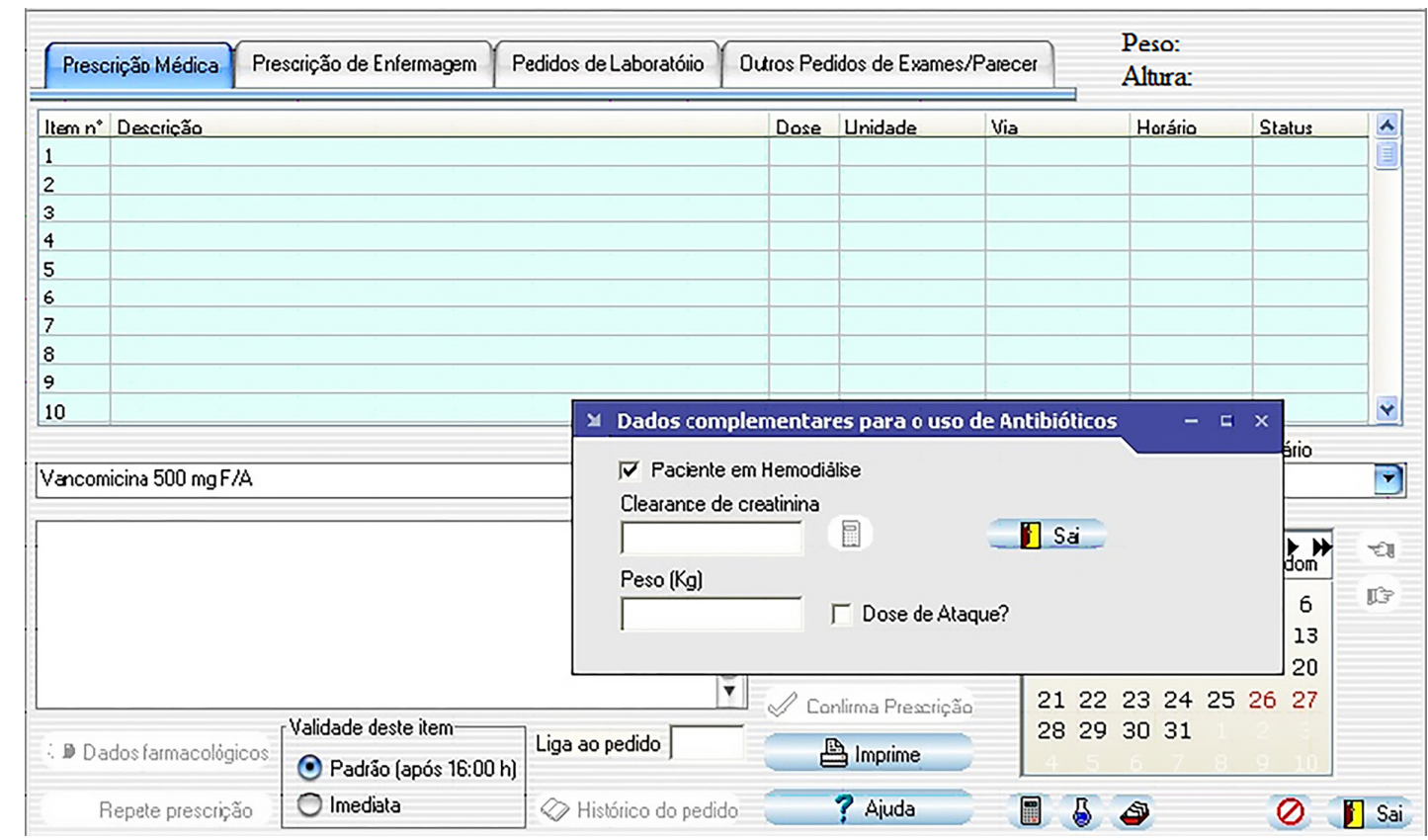

FIGURE 1 - Vancomycin e-prescribing chart sheet and window with requested patient parameters. Subtitle: Peso is Weight, Altura is Height. Dados complementares para o uso de antibióticos is Additional data for antibiotic dosing, Paciente em hemodiálise is Patient on hemodialysis, Clearance de creatinina is Estimated creatinine clearance, Dose de ataque? is loading dose? 
$2.250 \mathrm{mg}$ was recommended for patients with a TBW of $91-100 \mathrm{~kg}$.

It is relevant to ponder that in severe infections during the first hours of therapy when the bacteria burden is high, and while the host still has to mount an appropriate immune response, the antibiotics should be as effective as possible during this critical period, justifying more intensive VAN dosing. Nonetheless, there is a genuine concern over VAN-induced nephrotoxicity by dose maximization (van Hal, Paterson, Lodise, 2013).

In 2010, as a part of the antibiotic stewardship program, the VAN nomogram was implemented into the Medtrak e-prescribing system. This program has promoted an immediate impact on patient VAN dosage needs, increasing the probability of obtaining an initial optimal VAN dose. In a recent study, the applications of VAN nomograms showed that target serum VAN concentration were achieved in a higher number of patients with optimized dose regimen (Kullar et al., 2011). One considerable limitation of the present study is that the nomogram has yet to be validated and VAN serum concentration monitoring is necessary for the adjustment of maintenance doses.

\section{CONCLUSION}

The implementation of a VAN nomogram in a computer-based electronic program allowed a wideranging intervention in patient care with an immediate impact on updating VAN dosing that should be recognized as a powerful tool in antimicrobial stewardship programs.

\section{CONFLICT OF INTEREST}

The authors of this manuscript declare no conflicts of interest of any kind that would interfere with the development of this study.

\section{ACKNOWLEDGMENTS}

The authors would like to thank employees of the Hospital Infection Control Team and Ana Maria Pereira Rangel of the Computing and Network Centre of University Hospital Clementino Fraga Filho.

Rita de Cássia Elias Estrela Marins was funded by the Fundação de Amparo à Pesquisa do Estado do Rio de Janeiro (FAPERJ).

Tácio de Mendonça Lima was funded by the Coordenação de Aperfeiçoamento de Pessoal de Nível Superior (CAPES).

\section{REFERENCES}

BAUER, L.A. Applied clinical pharmacokinetics. 2.ed. New York: The McGraw-Hill Companies, 2008. 207p.

COCKCROFT, D.W.; GAULT, M.H. Prediction of creatinine clearance from serum creatinine. Nephron, v.16, n.1, p.3141, 1976.

DAVID, M.Z.; DAUM, R.S. Community-associated methicillinresistant staphylococcus aureus: epidemiology and clinical consequences of an emerging epidemic. Clin. Microbiol. Rev., v.23, n.3, p.616-687, 2010.

DRUSANO, G.L.; AMBROSE, P.G.; BHAVNANI, S.M.; RUBINO, C.M.; FORREST, A.; LOUIE, A.; LODISE, T.; RODVOLD, K.A. Vancomycin dose recommendations for hospital-, ventilator- or health care-associated pneumonia and the attainment of vancomycin trough concentrations of $15-20 \mathrm{mg} / \mathrm{L}$ : cognitive dissonance. In: ANNUAL MEETING OF THE INFECTIOUS DISEASES SOCIETY OF AMERICA, 45, 2007, San Diego. Abstracts. Virginia: Infectious Diseases Society of America, 2007. 447 p.

KULLAR, R.; LEONARD, S.N.; DAVIS, S.L.; DELGADO JR, G.; POGUE, J.M.; WAHBY, K.A.; FALCIONE, B.; RYBAK, M.J. Validation of the effectiveness of a vancomycin nomogram in achieving target trough concentrations of $15-20 \mathrm{mg} / \mathrm{L}$ suggested by the vancomycin consensus guidelines. Pharmacotherapy, v.31, n.5, p.411418, 2011.

LIU, C.; BAYER, A.; COSGROVE, S.E., DAUM, R.S.; FRIDKIN, S.K.; GORWITZ, R.J.; KAPLAN, S.L.; KARCHMER, A.W.; LEVINE, D.P.; MURRAY, B.E.; RYBAK, M.J.; TALAN, D.A.; CHAMBERS, H.F. Clinical practice guidelines by the infectious diseases society of America for the treatment of methicillin-resistant staphylococcus aureus infections in adults and children. Clin. Infect. Dis., v.52, n.3, p.18-55, 2011.

MOISE-BRODER, P.A.; FORREST, A.; BIRMINGHAM, M.C.; SCHENTAG, J.J. Pharmacodynamics of vancomycin and other antimicrobials in patients with staphylococcus aureus lower respiratory tract infections. Clin. Pharmacokinet., v.43, n.13, p.925-942, 2004. 
RYBAK, M.; LOMAESTRO, B.; ROTSCHAFER, J.C.; MOELLERING JR, R.; CRAIG, W.; BILLETER, M.; DALOVISIO, J.R.; LEVINE, D.P. Therapeutic monitoring of vancomycin in adult patients: a consensus review of the American Society of Health-System Pharmacists, the Infectious Diseases Society of America, and the Society of Infectious Diseases Pharmacists. Am. J. Health Syst. Pharm., v.66, n.1, p.82-98, 2009.

TAMMA, P.D.; COSGROVE, S.E. Antimicrobial stewardship. Infect. Dis. Clin. North Am., v.25, n.1, p.245-260, 2011.
VAN HAL, S.J.; PATERSON, D.L.; LODISE, T.P. Systematic review and meta-analysis of vancomycin-induced nephrotoxicity associated with dosing schedules that maintain troughs between 15 and 20 milligrams per liter. Antimicrob Agents Chemother, v.57, n. 2, p. 734-744, 2013.

Received for publication on $23^{\text {rd }}$ July 2013 Accepted for publication on $12^{\text {th }}$ November 2013 